\title{
A method of treating waste that is valuable as raw material to preserve the biosphere
}

\author{
Tatiana E. Marinchenko* \\ Rosinformagrotekh, Moscow region, Russia
}

\begin{abstract}
The introduction of livestock waste processing technologies is one of the ways to increase the efficiency and profitability of production, reduce the environmental burden and increase the competitiveness of producers, which lies in the concept of a green economy, as well as for the sustainable development of agriculture. Domestic technologies for processing poultry droppings, which increase production efficiency by reducing heating or feed costs and reduce the environmental burden due to timely processing, are discussed.
\end{abstract}

\section{Introduction}

The growing global consumption of poultry products has led to the emergence of a large number of droppings, which cannot be used in its original form in the future, and it carries a large burden on the environment when stored.

Theoretical and practical studies of the use of manure are performed all over the world. Various composting techniques and the subsequent introduction of droppings into the soil, as well as for biogas production, are widely used everywhere. Numerous studies emphasized the large potential of this waste as an untapped source of renewable energy through anaerobic digestion [1].

M. Mahadevaswamy and L.V. Venkataraman studied an integrated system for the bioconversion of poultry droppings for biogas production and utilization of the effluent for the production of the blue-green alga Spirulina platensis. The result was that poultry droppings produced $0.54 \mathrm{~m}^{3}$ of biogas per kilogram of Total Solids (TS). The $2 \%$ TS biogas plant effluent as sole nutrient medium for Sprirulina yielded 7-8 g dry algae a day. The biomass was harvested by filtration. The sundried algal biomass has been used as a poultry feed component. In economic terms the system appears promising [2].

Adrian Leip et al. suppose that droppings should be considered as a by-product until it is disposed of, wasted or used in excess of the nutrient requirements of crops, in which case it should be considered like waste [3].

Research is ongoing on the use of recycled droppings in feeding farm animals. L. M.Wadhwa and M.P. S. Bakshi noted in their work that agro-industrial wastes have become today's important feed resources for livestock and poultry [4].

C.N. Ncobela and M. Chimonyo also note that for sustainable intensification of village chickens, it is imperative to explore the potential of non-conventional feed resources [5].

\footnotetext{
*Corresponding author: 9419428@mail.ru
} 


\section{Materials and methods}

The material for the study was: scientific publications on the problems of the disposal of poultry waste by foreign and domestic authors, data on Russian developments in the study area. Methods were used: monographic method, comparative and system analysis, idealization and mental modeling, as well as a logical approach.

\section{Study results}

Understanding the need to reduce the environmental burden from poultry farms leads to the formation of a new management paradigm, that is to say, environmentally sound and environmentally friendly agricultural production. In this case, the criterion of environmental feasibility is the compliance of agricultural production with natural factors and the selection of the best technical and economic solutions to reduce the environmental load and energy costs, promote economically accessible and environmentally sound technologies, as well as managerial techniques aimed at introducing resource-saving and low-waste industries. Therefore, the idea of a closed cycle at a farm, which is both an environmental and an economic principle, is advisable. The resulting poultry production wastes form the basis for maintaining soil fertility or are recycled and put into circulation in the same or related industries. The use of biological origin agents to protect and control the crop and livestock products, as well as to stimulate the development of these products, lies in the principle of environmentally friendly agricultural production [6].

In accordance with the "Strategy for the Ecological Safety of the Russian Federation for the period until 2025," environmental safety must be ensured, among others, through the introduction of innovative and environmentally friendly technologies, and the development of environmentally friendly industries. Existing technologies for industrial production of agricultural products lead to inefficient consumption and loss of natural resources, and an increase in the environmental load.

According to estimates, economic losses and damage caused by environmental pollution and the deterioration of the quality of natural resources in Russia reach 4 to $6 \%$ of GDP annually, and taking into account the consequences for human health, those are equal to 10 to $15 \%$ of GDP.

Therefore, many agricultural producers are implementing measures to greening production, which involves the gradual restoration of natural fertility, increasing crop yields and animal productivity through biological methods of exposure, improving product quality, introducing and adapting energy- and resource-saving technologies.

Therefore, research continues in the field of droppings and manure recycling, new technologies and agents appear on the market, and an increasing volume of these wastes is being recycled [7].

An average of more than 200 metric tons of chicken litter or litterless droppings is formed per day at poultry farms. The intensive development of poultry farming has led to an aggravation of the ecological situation in the areas where poultry enterprises are located, most of which were designed and built in the last century near large cities. Poultry organizations found themselves in a difficult situation, i.e. the greater the production of eggs and poultry meat, the more problems there are with processing and, especially, with the sale of organic fertilizers. There is a need to dispose of bird droppings near the place of receipt (poultry enterprises) [8].

One of the most effective methods for the disposal of manure is such methods that increase production efficiency, including that by reducing production costs.

The poultry industry of the Russian Federation with an annual production of 44-47 billion eggs and more than 4.6 million metric tons of poultry meat is one of the largest energy 
consumers in the agribusiness: up to $12 \ldots 14 \%$ in the cost of its products is the energy component [9]. Therefore, some of the most effective methods are those that reduce the costs of enterprises on electricity and heating. This issue is more than relevant based on the fact that poultry products should be competitive at cost [9].

One of the promising areas for the utilization of poultry droppings is burning while obtaining thermal energy and mineral fertilizers (ash). Such a method of disposal is used, for example, in the Netherlands, at a plant with an installed electric capacity of $36 \mathrm{MW}$ and utilizing 400,000 metric tons of litter droppings annually. In Russia, such plants are available at Zagorsky Broiler LLC, Amur Broiler companies and Prioskolye JSC.

The staff of the All-Russian Research and Technological Institute of Poultry (VNITIP) of RAS, together with the specialists of Zagorsky Broiler LLC have performed a study to determine the efficiency of using a set of equipment (production of the Soyuz Kovrov Plant of Boiler-Furnace and Drying Equipment LLC and ThermoTechnoService LLC) for burning litter droppings to generate thermal energy and obtain mineral fertilizers (ash). Thermal technological tests have showed that the average specific consumption of litter droppings for the generation of $1 \mathrm{Gcal}$ of thermal energy is $585 \mathrm{~kg}$, i.e. 1 metric ton of poultry droppings with litter generates $1.71 \mathrm{Gcal}$ of thermal energy and 100-130 kg of mineral fertilizer (ash). An analysis of the chemical composition of the ash has showed that it is a valuable potassiumphosphorus-calcium mineral fertilizer with a composition of trace elements similar in composition to the ash obtained with burning wood fuel [10].

At the same time, when burning litter droppings, the emissions of harmful substances into the atmosphere do not exceed the maximum permissible rates (Table 1) [8].

Table 1. Flue gas composition during litter dropping burning.

\begin{tabular}{|l|l|}
\hline Amount of substances in flue gas $\left[\mathbf{m g} / \mathbf{m}^{\mathbf{3}}\right]$ & Values \\
\hline Ammonia & 2.53 \\
\hline Phenol & 0.097 \\
\hline Formaldehyde & 0.138 \\
\hline Soot & 1 \\
\hline Suspended solids & 21.7 \\
\hline Carbon monoxide & 26 \\
\hline Sulfur dioxide & 0 \\
\hline Nitric oxide & 198 \\
\hline Nitrogen dioxide & 1 \\
\hline
\end{tabular}

The annual economic benefit of operating a set of equipment at Zagorsky Broiler LLC when using poultry litter droppings is 3.95 million rubles. The payback period is 3.2 years [8].

Foreign studies have shown that processed droppings can be used as a safe source of nitrogen and minerals in concentrated feed mixtures. [4].

Research is actively being conducted on the use of processed droppings in feeding, as droppings are a promising feed resource. According to the Belarusian State Agricultural Academy, the feed value of the additive from dry droppings is 0.4-0.7 feeding units. Chicken manure contains $28-30 \%$ of protein, including all essential amino acids in an amount of at least $1.5 \%$. It also contains vitamins A, D, E, K, PP, B2, B6 and B12, such minerals as calcium, phosphorus, magnesium, potassium, copper, etc. It is 3 times higher than cattle manure in terms of nitrogen, phosphorus and potassium content.

The Uralbroiler poultry farms in the Chelyabinsk Region are implementing a pilot project to introduce technology for processing chicken manure into a feed additive using a hybrid 
technology based on a combination of various processes, one of the new and main components of which is the membrane application method developed by Russian Scientific Research Institute of Food Biotechnology and Energoresource-SP. The use of membrane technology allows obtaining two products from droppings at once: organic fertilizer and a feed supplement containing proteins, amino acids, and vitamins. R\&D showed that innovative baromembrane processes are very effective for the disposal of liquid litterless chicken manure, in particular: microfiltration, ultrafiltration, reverse osmosis and nanofiltration. The advantage of baromembrane processes is the absence of phase transitions and the need for heating the processed fluids, as well as the elimination of additional reagents and coolants. Therefore, they allow excluding thermal denaturation of biologically active substances.

In general terms, the process looks like this: the initial droppings are separated into sediment and filtrate. The precipitate is dried to produce valuable organic fertilizer. A feed additive is produced of the filtrate in the form of ultra-concentrate due to the filtrate deep purification and concentration of biologically valuable substances and using two membrane units. As a result, the droppings are completely processed. According to preliminary estimates, the payback period of the project will be 3 to 5 years.

The Stavropol State Agrarian University has developed a waste-free resource-saving technology for processing poultry waste to produce biogas (30 to $50 \%$ of the biogas is marketable); high-calorie feed additives for animals (nutritional value of $1 \mathrm{~kg}$ is 0.6 feed units); biologically active substances (BAS): means for combating diseases of winter cereals (root rot, Septoria blight, smut); granular organic fertilizers, which are collectively produced on the second day; traditional processes last 8 to 10 days.

Work in the field of poultry waste processing continues at the Novosibirsk State Agrarian University, L.K. Ernst All-Russian Research Institute of Livestock, and A. N. Severtsov Institute of Ecology and Evolution.

\section{Conclusions}

Using the latest achievements of scientific and technological progress to optimize work processes and recycle waste in animal husbandry is an obvious area for increasing the efficiency and profitability of production. Therefore, the introduction of modern waste processing technologies, which generally increase the profitability of production and reduce the environmental burden, is a timely measure and increases the competitiveness of manufacturers.

Most modern technologies for waste processing are aimed at using waste rather than destroying it and set the goal of maximizing the effect of their processing: obtaining effective fertilizers and biologically active substances for crop production, burning or obtaining biogas for energy purposes, feed additives that reduce the cost of feed goals etc.

The shift in the focus of public attention to the ecology of production stimulates research into the involvement of industrial waste in processing, as well as the introduction of modern technologies in the practice of production. In this regard, droppings are a good source of various substances useful for further agricultural use: biogas and thermal energy to reduce the need for burning natural hydrocarbons; fertilizers to restore land fertility; feed additives to reduce the need for vegetable and animal protein; environmentally neutral biologically active substances to protect and stimulate plant growth in order to reduce the chemical burden on the environment, etc. The discussed methods of disposal and recycling of droppings contribute to the preservation of the biosphere. 


\section{References}

1. W. Fuchs, Xuemei Wang, W. Gabauer, M. Ortner, Zifu Li Tackling Ammonia inhibition for efficient biogas production from chicken manure: Status and technical trends in Europe and China Renewable and Sustainable Energy Reviews 97 186-199 (2018) https://doi.org/10.1016/j.rser.2018.08.038.

2. M. Mahadevaswamy, L.V. Venkataraman Bioconversion of poultry droppings for biogas $\begin{array}{llllll}\text { and algal production Agricultural Wastes } & 18 & 2 & 93-101 & \text { (1986) }\end{array}$ https://doi.org/10.1016/0141-4607(86)90002-8.

3. A. Leip, S. Ledgard, A. Uwizeye, J.C.P. Palhares, M. F. Aller, B. Amon, M. Binder, C. M.d.S.Cordovil, C. De Camillis, Hongming Dong, A. Fusi, J. Helin, S. Hörtenhuber, A. N. Hristov, R. Koelsch, Chunjiang Liu, C. Masso, N. V. Nkongolo, Ying Wang The value of manure - Manure as co-product in life cycle assessment Journal of Environmental Management 2411 293-304 (2019) https://doi.org/10.1016/j.jenvman.2019.03.059.

4. L. M.Wadhwa, M.P. S.Bakshi Chapter 10 - Application of Waste-Derived Proteins in the Animal Feed Industry Protein Byproducts Transformation from Environmental Burden Into Value-Added Products 161-192 (2016) https://doi.org/10.1016/B978-0-12-8023914.00010-0.

5. C.N. Ncobela, M. Chimonyo Potential of using non-conventional animal protein sources for sustainable intensification of scavenging village chickens: A review Animal Feed $\begin{array}{lllll}\text { Science } & \text { and } & \text { Technology } & 208 & 1-11\end{array}$ https://doi.org/10.1016/j.anifeedsci.2015.07.005.

6. Yu.S. Larionov Biofarming as a new paradigm of ecologically safe agricultural production Interexpo Geo-Siberia. 2 (2013), available at: https://cyberleninka.ru/article/n/biozemledelie-kak-novaya-paradigma-ekologicheskibezopasnogo-selskohozyaystvennogo-proizvodstva.

7. Biotechnology to help farmers, available at: http://www.tambov-apk.ru/articles/3898/.

8. V.G. Shol, V.P. Lysenko, V.A. Gusev, L.A. Zazykina, T.N. Kuzmina Summary Promising technology of poultry manure recovery while generating heat energy and obtaining mineral fertilizer Machinery and equipment for rural area 1 25-29 (2018)

9. I.P. Saleeva, A.V. Sklyar, T. E. Marinchenko, M.V. Postnova, A.V. Ivanov, A.I. Tikhomirov Efficiency of alternative electric power industry of poultry farming E3S Web of Conferences 124 (2019) DOI: 10.1051/e3sconf/201912404020.

10. Nano-disposal: scientists have developed cost-effective technologies for waste disposal Agro-technology and technology $\mathbf{0 1}$
https://www.agroinvestor.ru/technologies/article/25631-/. 